This is an original accepted manuscript of an article published by Taylor \& Francis in Current Issues in Language Planning (2014), available online:

https://www.tandfonline.com/doi/full/10.1080/14664208.2014.972535

Accepted version downloaded from SOAS Research Online: http://eprints.soas.ac.uk/21243

\title{
"I'm Not Dead Yet": A Comparative Study of Indigenous Language Revitalization in the Isle of Man, Jersey and Guernsey
}

\author{
Gary N. Wilson ${ }^{\mathrm{a} *}$, Henry Johnson ${ }^{\mathrm{b}}$ and Julia Sallabank ${ }^{\mathrm{c}}$
}

\begin{abstract}
At the outset of the $21^{\text {st }}$ century, the survival of many minority and indigenous languages is threatened by globalization and the ubiquity of dominant languages such as English in the worlds of communication and commerce. In a number of cases, these negative trends are being resisted by grassroots activists and governments. Indeed, there are many examples of activists and governments working together in this manner to preserve and revitalize indigenous languages and cultures. Such coordinated efforts are vital to the success of language revitalization. This article compares the work of language activists and governments in three small island jurisdictions in the British Isles: the Isle of Man, Jersey and Guernsey. Comparison between these cases is greatly facilitated by similarities in their political, economic and demographic circumstances. The cases, however, reveal important differences in the way that activists and governments have responded to the challenges of language revitalization, as well as some interesting insights on the future prospects of the indigenous languages of these small island jurisdictions.
\end{abstract}

\section{Keywords}

Government; grassroots activists; language revitalization; Manx; Jèrriais; Guernesiais

\section{Introduction}

Small regions throughout the world face a number of significant and daunting challenges at the outset of the $21^{\text {st }}$ century. One of these involves the fate of minority and indigenous languages. The ubiquity of English and other major languages in the worlds of communication and commerce, coupled with the grinding social, economic and political impacts of globalization, threaten to relegate fragile and vulnerable languages even further to the margins of their respective societies.

At the same time, there is considerable evidence to suggest that members of indigenous language communities are resisting this trend, through a combination of grassroots activism and government support. Grassroots activists are primarily motivated by a desire to preserve a language and the broader cultural identity in which that language is embedded. Governments

\footnotetext{
${ }^{\text {a }}$ Department of Political Science, University of Northern British Columbia, Prince George, Canada;

* Corresponding author. Email: wilsong@unbc.ca

${ }^{\mathrm{b}}$ University of Otago, New Zealand

${ }^{c}$ Linguistics Department, SOAS, University of London
} 
may share this goal, but they are often more persuaded by the external value of language and the role it can play in distinguishing and positioning a particular place in an increasingly competitive and globalized economy.

Grassroots activists usually form the advanced guard (or in some cases a desperate rearguard) of language revitalization. Their activism, which is frequently voluntary, is often the remaining bulwark against language death. Governments, on the other hand, tend to engage in language revitalization once the grassroots activists have created a firm foundation on which to build. There are many examples of activists and governments working together in this manner to preserve and revitalize indigenous languages and cultures. Such coordinated efforts are vital to the success of language revitalization (Spolsky, 2004).

There is, however, a fine balance between grassroots activism and government support for language revitalization. In some cases, for example, overly aggressive government support for minority languages has encouraged speakers to become passive recipients of language planning rather than active participants. The result is a lack of enthusiasm for language revitalization and maintenance (Fennell, 1981; Grenoble and Whaley, 2006). Our observations and discussions with language scholars and activists suggest that voluntary activism can wither as official government support grows. In part, this may be due to misleading perceptions about the health or the future of the language among the general population, once the government starts to play a more official role in language planning. Another possible reason is that volunteers may see less need for their contributions if government agencies take over language planning and policy; or they may feel that voluntary efforts are less valued than those of paid officials. There may also be evidence of significant tensions between governments and activists over the direction and scope of language policy.

While the formal institutionalization of language policy and the withering away of less formal grassroots networks could be an indication that a language has stabilized, the decline of grassroots activism cannot be viewed as a positive development. A robust and broad network of voluntary activists is necessary at all times, even when the language appears to have achieved a stable footing. Government support for language revitalization and planning can wax and wane depending on a myriad of competing political or economic circumstances, whereas voluntary activists remain more committed to the language regardless of the political, economic and social circumstances facing society.

With these issues in mind, this paper compares the process of language revitalization in the context of three small island jurisdictions in the British Isles: the Isle of Man, Jersey and Guernsey. In all three cases, grassroots activists and governments have played a pivotal and complementary role in language revitalization over the last several decades. Despite once having the most endangered language, the Isle of Man has made the most progress in terms of the institutionalization of its indigenous language, Manx Gaelic (Manx). The Isle of Man has also begun the process of creating a proficient new speaker community through its education programming at the primary, secondary and adult levels. In recent years, Jersey and Guernsey have attempted to follow a similar path, often looking towards the Isle of Man for ideas and 
support. However, significant questions remain in all three islands about future sustainability of revitalization efforts. Over the last several decades, economic growth in these islands has provided significant resources for linguistic and cultural revitalization (Wilson, 2011). But given the uncertainties of the global economy and the specific threats facing the economies of these three islands, the key to the future success of language revitalization will be to sustain and grow grassroots activism.

Language planning is now rarely seen as only top-down, although larger programs are still most frequently reported in the literature. Kaplan and Baldauf (1997) suggest a "macro meso - micro" framework, noting that traditionally language planning is understood as taking place at the macro (governmental) and the meso (regional) levels. In the small island jurisdictions discussed in this paper, these two levels are frequently the same. 'Micro' level refers to language use in particular circumstances, particularly schools, but also businesses and other institutions. Grass-roots groups undertake language planning at 'micro' level, at least in the initial campaigning stages of language revitalization efforts. Bottom-up efforts may also be characterized by more enthusiasm than planning, leading to what Baldauf (1994) terms 'unplanned language planning'. Government policies in support of minority languages can provide much-needed direction and resources, but as noted above, at the risk of institutionalization and loss of grass-roots motivation. The first part of this article explores the reasons for choosing comparison as a methodological tool, and provides a general overview of the political, economic and cultural similarities that link the three case studies. Part two examines the process of language revitalization in each jurisdiction, paying particular attention to the roles played by grassroots activists and governments in language revitalization and planning. A particular focus of this section will be the ever-evolving relationship between activists and government. The final part of the paper reviews the similarities and differences between the three cases, and draws some general conclusions about the future of language revitalization in these small island jurisdictions.

\section{Comparison as a Methodological Approach}

As a methodological approach, comparison allows researchers to juxtapose different cases for the purpose of identifying and explaining similarities and differences in outcomes across cases. Comparison can also serve as a useful means of testing or elaborating theories, and developing generalizable conclusions about social phenomena. This study uses comparison as a means of examining the process and outcomes of indigenous language revitalization in three small island jurisdictions ${ }^{1}$ in the British Isles. ${ }^{2}$ Such comparisons yield insights that can be used to study linguistic and cultural revitalization in other cases.

Comparison is most effective when cases have similar features. Such similarities allow the researcher to discount certain variables when developing an explanatory theory. In this paper, comparison between cases is greatly facilitated by a number of similarities between the three cases under examination. First and foremost, the Isle of Man, Jersey and Guernsey are relatively 
small islands, located in the British Isles. Second, these islands are all Dependencies of the British Crown. They are not part of the United Kingdom, nor are they members of the European Union. ${ }^{3}$ As such, they have considerable domestic autonomy compared to many other subnational regions in Europe. All three islands have their own parliaments with law-making authority in their respective jurisdictions, and do not send representatives to the British Parliament in Westminster. At the same time, they and their populations have important links to the United Kingdom.

Over the last five decades, these islands have undergone considerable economic change, transitioning from economies centered on traditional industries such as fishing, agriculture and tourism to post-industrial economies based on banking and financial services. While it could be argued that this transition has had both positive and negative impacts on the islands and their inhabitants, it has provided higher and stable rates of economic growth which, in turn, has translated into increased revenues for government and a higher standard of living for most islanders compared to other regions in the British Isles and Europe.

Another consequence of this economic transition is that the Isle of Man, Jersey and Guernsey have also experienced significant demographic change over the last several decades. An influx of newcomers has boosted the population of these islands and, in doing so, has reduced the indigenous portion of the overall population, which is seen by some local people as a major factor in language shift. While there is evidence that demographic change can have a negative impact on indigenous societies and their respective cultures, some research has shown that some newcomers with little or no connection to the places where they relocate become passionate supporters of indigenous culture and language (Wilson, 2009).

One of the most interesting aspects of recent cultural transformation in all three islands is the revitalization of their indigenous languages. The case studies in this article examine this revitalization process in more detail, but suffice it to say that after years of decline, the indigenous languages of the Isle of Man (Manx), Jersey (Jèrriais) and Guernsey (Guernesiais) are going through a period of revival and renewed interest. In all three cases, the revival was initially driven by grassroots language activists, but more recently has been supported by government, to varying extents. In many respects, this revitalization process is consistent with and reflective of some of the broader changes occurring in these island societies.

Most research on language and culture in the Isle of Man, Jersey and Guernsey involves single case studies that examine each case in isolation (e.g. Wilson, 2009; Clague, 2009; Johnson, 2008; Jones, 2009; Sallabank, 2005; 2006). Given the similarities in these cases, however, it stands to reason that a comparative study would shed light on the process of language revitalization, as well as the factors that affect this process and the outcomes that are generated. The case studies begin by providing a brief overview of each island: location, political status, economy, demography and the recent history of its indigenous language. Each case study then discusses the relationships between grassroots activists and government in the language revitalization and planning process, focusing specifically on how this relationship has evolved over time. The article concludes by reviewing the main similarities and differences between the 
case studies in order to reach some generalizable conclusions about the relationship between grassroots activists and governments in the areas of language planning and revitalization.

\section{The Isle of Man}

The Isle of Man is a small island (572 sq. km.) in the middle of the Irish Sea, roughly equidistant from England, Scotland, Wales and Ireland. According to the 2011 census, its population is 84,407 (Isle of Man Government, 2013). For most of its history, the island has come under the political, economic and cultural influences of its Irish Sea neighbours, in particular England and Scotland. Despite these influences, the Isle of Man has retained its own unique language and culture. Until the $18^{\text {th }}$ century, Manx Gaelic (Manx), a Goidelic language closely related to Irish and Scottish Gaelic, was spoken universally on the island. The language went into decline after the British Crown took direct control over the island in 1765 (Gawne, 2002). The ensuing decline of the traditional economy and government legislation aimed at assimilation, coupled with the emigration of many Manx-speakers to other parts of the British Empire and the United States, and the reinvention of the island as a destination for Englishspeaking tourists from the British Isles, marginalized the language and contributed to its slow decline. By 1961, only 165 people spoke Manx and in 1974, the last native speaker of the language died (Gawne, 2002).

Since the 1970s, Manx has undergone a process of revitalization, due in large part to the efforts of a dedicated group of language activists. The recent history of language activism and language planning in the Isle of Man can be divided into two areas: the work of grassroots language activists and the critical supporting role played by the Isle of Man government. It is important to note the synergies that exist between language activists and government, with the most obvious example being the Manx Heritage Foundation, a not-for-profit group that has been involved in various aspects of language planning since it was founded in 1982. Collaboration between language activists and government, however, also extends to more formal initiatives such as the Bunscoill Ghaelgagh, a Manx-medium primary school, and the Manx Language Unit (Yn Unnid Gaelgagh), a peripatetic unit which oversees the teaching of Manx in the Englishlanguage schools (Wilson, 2009).

\section{Grassroots Language Activism}

Over the course of the $20^{\text {th }}$ century, a number of efforts were made to preserve the language. In 1899, language activists created Yn Chesaght Ghailckagh (The Manx Gaelic Society), which continues to serve as the formal guardian of the language. Various researchers and language scholars came to the island to study Manx in the first half of the $20^{\text {th }}$ century and in 1948, the Irish Taoiseach, Eamon de Valera, commissioned the Irish Folklore Society to record the last native speakers. Indeed, it is important to note that while many of the language activists 
who would spearhead the revitalization of Manx in the 1980s and 1990s were not native speakers, they learned the language from the last native speakers. The efforts of these early language activists to revitalize the language in the 1970s and 1980s were largely met with hostility and contempt from islanders who had grown up regarding Manx as a dying and worthless language. It was determined efforts of these early activists, however, that would provide the foundation on which the current generation of activists is rebuilding the status of the language.

By the 1990s, language activists realized the need to teach Manx to the next generation of speakers. In 1996, they created the Mooinjer Veggey program, "an educational charity promoting knowledge and the use of Manx Gaelic to children from early years upwards" (Mooinjer Veggey, 2013). In time, this program would become a very important building block and support mechanism in a comprehensive program of Manx language education that includes the abovementioned Bunscoill Ghaelgagh and Yn Unnid Gaelgagh. Language activists were also instrumental throughout the 1990s and into the 2000s in terms of lobbying government. In some cases, members of the language community became active in government, thereby creating a tangible and important link between the government and the language community.

\section{Government Support for Language Revitalization}

Alongside the work of the language activists, a number of other developments were taking shape that would provide support to the language revitalization process. By the mid1980s, the Isle of Man had made significant progress towards self-government (Kermode, 2001). This coincided with (and was connected to) a period of significant growth in the island's economy. As Wilson (2010) has argued, these broader processes created a more favourable environment in which to revitalize the language and culture of the island. Such changes also spurred the government into action. In 1982, Tynwald, the island's parliament, created the Manx Heritage Foundation, a not-for-profit organization that supports and promote Manx culture.

In 1984, Tynwald passed a motion which, among other matters, declared: "That Manx Gaelic should be supported and encouraged by all agencies of Government and Boards of Tynwald so far as they are practically able" (Gawne, 2002: 174). Tynwald commissioned the Select Committee on the Greater Use of Manx Gaelic, whose report was approved in July 1985. These actions represented the first of a number of important steps taken by the government in the area of language revitalization.

In 1990, a poll was conducted on the quality of life on the island which revealed that $36 \%$ of respondents favoured the teaching of Manx in the school system (Clague, 2009, p. 175). The results of this poll prompted the appointment of the island's first Language Officer ( $\mathrm{Yn}$ Greinneyder) in 1992. ${ }^{4}$ The primary role of the Manx Language Officer (MLO) is to "raise the profile of Manx Gaelic both within the island and internationally and to assist organizations who work to support the language" (Manx Heritage Foundation, 2013). For the last two decades, therefore, the MLO has served as a very important link between the language community and 
government. The MLO is an employee of the Manx Heritage Foundation (MHF) and works alongside the Manx Music Development Officer to promote the language and culture of the island. Approximately one-quarter of the MHF's funding comes from an annual grant from Tynwald. ${ }^{5}$ Island politicians are also active on the Board of Directors, alongside community members.

In conjunction with the MHF, the MLO has produced a language development program that focuses on the following areas of language planning:

- Planning for Language Learning: includes supporting language transmission in the family, pre-school and at Manx Medium education level.

- Planning for Language Use: includes the promotion of cultural tourism and developing the use of Manx in the public, private and voluntary sectors.

- Status Planning: the visibility of the language needs to be raised and Government encouraged to work towards compliance with the European Charter for Regional and Minority Languages.

- Corpus planning: the need for linguistic standardisation and the development of specialised terminology (Manx Heritage Foundation, 2013)

These areas generally conform to the accepted components of language planning and reveal a comprehensive plan for the development of the language in the future.

\section{Future Opportunities and Challenges}

The Manx Heritage Foundation has emerged as the coordinating body both within and between grassroots and government-led initiatives in linguistic and cultural revitalization. Although the language community on the island is still very small, considerable efforts have been made to grow the community at all levels. For example, the establishment of a Manxmedium primary school has been one of the most important developments in the revitalization process because it has produced a cohort of language speakers among the younger generation (Wilson, 2009). The Bunscoill Ghaelgagh serves as an example of collaboration between government, through the Department of Education and Children, and educational and cultural charities like Mooinjer Veggey and the MHF, and the broader grassroots language community, which lobbied the government to create the school and provides critical support to the school as it grows in size.

In addition to playing an important role in the success of the Bunscoill Ghaelgagh, the MLO and MHF have also been active in other areas of language planning, such as growing the cohort of adult speakers and raise the profile of the language on and off the island. One particular area that the current MLO, Adrian Cain, has been focusing much of his attention is on social media. Manx lessons are available as evening and lunchtime classes, and on-line through the Ynsee Gaelg (Learn Conversational Manx) website (Ynsee Gaelg, 2013) and language is being promoted through social media forums such as Facebook, Twitter and YouTube (Qualtrough, 
2012). While this activity is part of a general media campaign to promote the language, it is specifically targeted at retaining the interest of the younger generation of speakers that is now active in the language community.

As regards the heath of the grassroots community in the future, conversations with language educators on the island suggest that this community has grown, not only with the addition of the younger generation of speakers, but also among the adult population. One informant commented that there was a time when she knew everyone in the language community, whereas now she meets new people who speak the language and are active in the community. At the same time, there is a concern that the 'heavy lifting' of language activism is being borne by too few people. As the current generation of language activists ages, it is critical that newcomers to the language community and, especially, the younger generation of speakers play an active role in all areas of language planning.

Maintaining an active grassroots language community will become even more important as the island's government tries to deal with the economic and political impact of the global financial crisis. For many decades, the Isle of Man has enjoyed strong economic growth, largely as a result of its involvement in the offshore banking and financial services sectors. This growth has, in turn, provided the island's government with the resources to invest in language planning (Wilson, 2008). The programs initiated in the education system are evidence of this support. So too is the Manx Heritage Foundation which, as noted above, relies on an annual government grant for a significant part of its funding.

The global financial crisis has not only led to a decline in the banking and financial services sectors in general, but it has also renewed demands to curtail the activities of offshore banking centers like the Isle of Man and Channel Islands. In an era of economic austerity, government support for language planning activities could be threatened, leaving the language community to carry on as best they can. Language activists on the island are taking steps to fill this potential gap in support by creating a grassroots organization called Pobble. ${ }^{6}$ The goal of Pobble is to support Manx as a community asset through education, outreach and the mobilization of a new generation of activists who can ensure "that the language plays its part in making the Island a prosperous, culturally vibrant place that we can be proud to live in" (Pobble, 2013).

\section{Jersey}

Jersey is the largest of the Channel Islands. It has an area of $119.6 \mathrm{~km}^{2}$ (45 square miles) and is geographically located $22.5 \mathrm{~km}$ (14 miles) west of the Cotentin Peninsula in northern France. The island is about $136.8 \mathrm{~km}$ (85 miles) from the south of England (States of Jersey Statistics Unit 2012a, iii). In 2012, Jersey's population was estimated to be 99,000 (States of Jersey Statistics Unit 2012b, 1). While historically many Jersey residents had French ancestry, and English migration to the island grew rapidly throughout the twentieth century, more recently 
the island has experienced new forms of migration. In 2011 , only $50 \%$ of islanders were born on Jersey, with other residents born in the British Isles (31\%), Portugal/Madeira (7\%), the Republic of Ireland (2\%), other European countries including Poland (6\%), and elsewhere (4\%) (States of Jersey Statistics Unit, 2012a: 43).

For many centuries the lingua franca of the island was Jèrriais (also known as Jersey Norman French, Jersey French and patois). Many islanders would have spoken Jèrriais (of which there are several dialects on the island) alongside English and French, thus offering tri-lingualism as a necessary means of local and regional communication. Throughout the twentieth century the use of Jèrriais went through a period of rapid decline as a result of the increased Anglicization of the island. Although a survey in 2012 noted that the proportion of people on Jersey who were able to understand a few common Jèrriais words or phrases was about one third of the population, the actual number of fluent speakers was thought to be less than 100 (States of Jersey Statistics Unit, 2012a, 56).

Over the past few decades there has been increased cultural interest in Jèrriais and language revitalization (e.g. Jones, 2000; 2001). Although Jèrriais continues to decline in terms of the number of native or fluent speakers, there is wide acknowledgement of the language as part of the island's cultural heritage and identity, and there has been increased public awareness and interest in its promotion and preservation, from language educators, school teachers, cultural organizations and government departments.

\section{Grassroots Language Activism}

There are several Jersey-based cultural organizations that promote Jèrriais, including L'Office du Jèrriais (established in 1998), ${ }^{7}$ Le Don Balleine Trust (established in 1951), $L^{\prime}$ 'Assembliée d'Jèrriais ${ }^{8}$ (established in 1951), La Section dé la Langue Jèrriaise (established in 1996) of La Société Jersiaise, and Lé Congrès des Parlers Normands et Jèrriais, an umbrella organization representing each of the above. There are also several pan-Norman organizations such as L'Association Jersey-Coutançais (established in the early 1980s). Other contexts where Jèrriais is publicly expressed include La Fête Nouormande (an annual Norman festival, also known as La Fête des Rouaisouns, which maintains links with other Norman areas including Guernsey - see: Johnson, 2008), Jersey Evening Post (with a regular Jèrriais column), BBC Radio Jersey (with a weekly Jèrriais program: Lettre Jèrriaise), and the Jersey Eisteddfod (a competition that includes speech and performance).

L'Office du Jèrriais has been pivotal in helping teach and promote Jèrriais in primary, secondary and adult education, and in publicizing the language more widely. A Jersey Language Teaching Coordinator was appointed in 1998, and L'Office du Jèrriais started teaching primary school classes in 1999 with 170 students (the numbers have fluctuated around this figure ever since) (States of Jersey, 2010; States of Jersey, Education, Sport and Culture Committee, 2005b). The Office is run by Le Don Balleine Trust and receives its main funding from the States of Jersey (Jersey's government) through the Department of Education, Sport and Culture. 
In 2011 , there were 24 primary schools and seven secondary schools participating in the program, as well as four types of classes for adult learners. In terms of student numbers, there were 180 primary, 19 secondary and 25 adult learners (States of Jersey Statistics Unit, 2012a, 56). L'Office du Jèrriais took over the running of adult classes in Jèrriais in 2004 from the Education, Sport and Culture Committee, which had been holding Jèrriais classes since 1967 (Jones and Singh, 2005, 119; States of Jersey, Education, Sport and Culture Committee, 2005b), and there are usually around 25-30 adults enrolled in the program each year. Furthermore, rather than having L'Office du Jèrriais offer voluntary Jèrriais classes at some primary schools during lunchtimes or after school, four primary schools now act as Pallions - meaning a place to meet and talk - for voluntary, after-school tuition in Jèrriais. A recognized Jèrriais qualification (equivalent to a General Certificate of Secondary Education) is also available at the secondary level, and while several students are currently taking this course, no students had passed the exam at the time of writing. In addition to these teaching activities, the staff of $L$ 'Office $d u$ Jèrriais edits and produces the quarterly Jèrriais journal Les Nouvelles Chroniques du Don Balleine, and has produced numerous publications including several dictionaries and teaching booklets. It also maintains a website that is abundant in information about the language and the culture of the island. ${ }^{9}$

\section{Government Support for Language Revitalization}

Over the past decade, Jèrriais has featured prominently in the political discourse of some States' departments. For example, the Development of a Cultural Strategy for the Island (States of Jersey, Education, Sport and Culture Committee, 2005a) stresses the importance of local culture and, in particular, clearly articulates the need to rejuvenate Jèrriais in the twenty-first century: "Language brings distinctiveness, a sense of localness and a whole new set of skills all of which are important qualities in attracting the creative economy. It is fundamental to the Island's identity" (States of Jersey, Education, Sport and Culture Committee, 2005a; see also Le Rendu 2004; Riddell, 2007). Objective 1.9 of this document specifically mentions Jèrriais: "To investigate the feasibility of adopting Jèrriais as the Island's official minority language and . . to revive the language of Jèrriais" (States of Jersey, Education, Sport and Culture Committee 2005a). As the first major political strategy for revitalizing Jèrriais, the document has been regularly reviewed with achievements noted. ${ }^{10}$

In this political context, the States of Jersey has not formally produced a distinct language strategy for the island, nor has it made Jèrriais an official language of Jersey. However, some progress has been made through Jersey's involvement in the British-Irish Council, which "comprises representatives of the Irish and British governments and of the devolved institutions in Northern Ireland, Scotland and Wales, together with representatives of the Isle of Man, Guernsey and Jersey" (British-Irish Council, 2012). One of the Council's areas of work is indigenous, minority and lesser-used languages, and it is within this framework that Jèrriais is recognized. Nevertheless, unlike Welsh, Gaelic Scots, Ulster Scots, Cornish and Manx, Jèrriais is 
yet to be recognized under the European Charter for Regional and Minority Languages (cf. Britain, 2007; Council of Europe, 2010; Trudgill, 1984). Indeed, in a debate on Jèrriais and the European Charter for Regional and Minority Languages, the members of the States of Jersey actually voted in favour of not mentioning this Charter in its Strategic Plan 2006-2011 because of the demands on the government if it officially registered Jèrriais with the Charter (States of Jersey, 2006a; 2006b). Jèrriais or language in general is also not mentioned in the Strategic Plan 2009-2014 (States of Jersey, 2009).

While there is increasingly more signage in Jèrriais in various heritage sites and everyday contexts around the island, the only major top-down intervention in the area of compulsory education occurred in 2012 when the Department of Education, Sport and Culture, in collaboration with L'Office du Jèrriais, initiated a revised school program in Jersey Studies, which includes six compulsory Jèrriais classes (one per week) in Year 4 (8 and 9 year olds) at the primary level as part of a citizenship strand of the curriculum. Such a move offers an opportunity for all school students to learn more about Jèrriais, and opens avenues for further development of teaching programs in the future. All other teaching activities at every level of education are on a voluntary basis, and L'Office du Jèrriais is able to provide teaching support through one of its Jèrriais programs.

\section{Future Opportunities and Challenges}

In a context of language maintenance and revitalization, the last few decades have witnessed a broader local interest in Jèrriais, much of which is a result of local organizations continuing to promote the language. As well as La Fête Nouormande offering a distinctly public face to Jèrriais and its related languages (i.e., Norman and Guernesiais), ${ }^{11}$ there are other public celebrations that often have a Jèrriais presence in the form of language promotion by $L$ 'Office $d u$ Jèrriais as a staged event, including La Fête du Cidre (Cider Festival), Fête de Noué (Christmas Festival), La Fête de Saint Hélier (St Helier Festival), and La Séthée d'Nièr Beurre (Black Butter Evening). With the exception of La Séthée d'Nièr Beurre, each of these hyper-traditional placemaking events has only become a formalized part of island life in recent years; yet they all have a sense of authenticity at their core (cf. Hobsbawm and Ranger, 1983; Eco, 1986; Wilkins, 2000). Each event shares an aspect that includes Jèrriais, whether used by native or secondlanguage speakers, or through its presence in song, signage, translation or promotional materials. Nevertheless, the language speakers tend to be of an older generation and younger fluent speakers are lacking in number.

While Jersey's Jèrriais language planning strategy is essentially linked to organizations and events, language revitalization is further connected to broader cultural areas that have been influenced by the more recent public promotion of and interest in Jèrriais. Some new bilingual signage has appeared in prominent public spaces, including recycling bins in St Helier, parking signs at Jersey Heritage Trust, and a new brand of cheese launched in 2008 and called Lé Fronmage. Furthermore, Jersey's own currency (the Jersey pound) now features new banknotes 
that celebrate the island's trilingual cultural heritage (English on the front, and French and Jèrriais on the reverse). A cider-making company established in 2005, La Robeline Cider Company, uses Jèrriais branding on the label for its bottles, "Cidre dé Jèrri", and in 2001, Jersey Post issued a series of stamps that included Jèrriais names of island mills, which were depicted below the English name. Also, a pop-folk band that sings in Jèrriais was established in 2012 in collaboration with L'Office du Jèrriais. The band produced recordings for inclusion in a school resource on Jèrriais (L'Office du Jèrriais, 2012), and in the same year released Jersey's first popfolk album of Jèrriais songs (Badlabecques, 2012). Such symbols of the island's living linguistic heritage do much to highlight the importance of this minority and endangered language, and also help maintain its presence as a powerful icon of island identity.

The promotion of Jèrriais in the twenty-first century has many challenges and opportunities. At a time when Jersey, like Guernsey and the Isle of Man, is increasingly asserting its unique political status on the world stage, primarily as a result of its flourishing fiscal performance in the global finance industry, it is also looking inward and celebrating its cultural heritage as part of its island identity (Fleury and Johnson, 2013). In this context, Jèrriais is an emblem of island heritage. However, whether or not the language is maintained with new proficient speakers will depend on several factors. Firstly, the States of Jersey has yet to commit itself to a major Jèrriais language policy whereby all school children are required to learn the language as part of compulsory schooling that is beyond the six language classes at primary level as part of the Jersey Studies classes. Secondly, grassroots activists are working with limited resources and have yet to produce distinct new communities of fluent Jèrriais speakers. In the present day, therefore, it seems that Jèrriais is at a juncture where the development of a culture of new speakers is uncertain, but at the same time there is increased awareness and knowledge of the language in one form or another that is contributing in part to a new island identity.

\section{Guernsey}

Guernsey is the second largest of the Channel Islands, located approximately 22 miles $(35 \mathrm{~km})$ north-west of Jersey and 70 miles $(110 \mathrm{~km})$ south of England. It the administrative centre of the Bailiwick of Guernsey, which comprises Alderney, Sark, and several smaller islands. This case study discusses Guernesiais ${ }^{12}$, the language of the island of Guernsey itself, which is the only Bailiwick language variety that has so far been the subject of revitalisation efforts. The last speakers of Auregnais, the language of Alderney, are thought to have died in the 1960s. There are very few remaining speakers of Serquiais, the language of Sark. In 2007 Mari Jones (personal communication) located twelve on the island; twenty potential speakers were identified in 2009 by Yan Marquis through local contacts, but at least two have since died.

In the 2001 census, 1,327 people (2.2\% of the population of Guernsey) reported speaking Guernesiais fluently. Two-thirds of this number, however, was aged 64 and over. There are no current official figures, ${ }^{13}$ but the number of speakers appears to have fallen drastically since 
2001 , to the extent that it is becoming difficult to find fully fluent speakers to record for language documentation (Marquis and Sallabank, 2013). At the time of writing there are thought to be only five people under the age of 60 who are capable of holding a sustained, impromptu conversation in Guernesiais.

Linguistically Guernesiais, Jèrriais and the other former Channel Islands vernaculars are branches of Norman, part of the Oïl language family of northern France. Traditionally, Channel Islands language varieties have been seen as dialects or patois of French, with which they were the Low partners in a diglossic relationship. Until the $20^{\text {th }}$ century, French was the language of education, literacy, religion and officialdom; inexorably this role was assumed by English (Crossan, 2008). Although many islanders profess a strong emotional attachment for Guernesiais (Sallabank, 2006; 2013), along with the other island languages it had low social prestige and no official status.

Although Jones $(2001,2007)$ refers to them as dialects, it has become a tenet of many language supporters in Guernsey and Jersey that their varieties should be construed not as dialects of French but as languages in their own right, in order to reclaim prestige. According to one informant:

When I was at school [1960s], it was the perception that Guernsey French was an inferior language, a language of peasants! One was looked down upon as being 'countrified' if one was associated with the language. There seemed to be no comprehension, or if there was, no acceptance, that Norman French was the language of William the Conqueror; that it preceded French; that it is our heritage! As such, I feel strongly that it should not be allowed to disappear ... I believe there has to be a greater effort yet to promote the language at the political level, at this eleventh hour, so as to try to ensure that our own heritage is preserved.

\section{Grassroots Language Activism}

Until 2007 there was little or no official support for Guernesiais and most language support activities could be classed as 'grass-roots' or 'bottom-up' (Sallabank, 2005); in other words, run by voluntary groups and individuals. These activities focus on two main areas: performance in cultural festivals and formal lessons for children.

Cultural festivals are an enjoyable, relatively uncontroversial language activity, and before 2007 they were the only type of activity which attracted official funding in Guernsey. The main annual language festival is the 'Guernsey-French' section of the Eisteddfod, a general cultural festival. ${ }^{14}$ This competitive event is now one of the few opportunities to speak and hear Guernesiais publicly. It includes recitations of poems, short stories and Bible readings, songs, sketches and plays. Many participants dress up in old-fashioned clothes (not necessarily traditional dress) and there is a strong feeling of nostalgia, in the words of the 2011 adjudicator, for 'the language of our youth... of our grandfathers'. As mentioned with regard to Jersey, the 
cultural focus tends to cater to the tastes of older participants and audience members (despite increased participation by children), which may give the impression that Guernesiais is a language of the past. Although older participants and audience members welcome the opportunity to celebrate what they see as their traditional culture, some young adult learners of Guernesiais have stated that they do not find the event appealing.

Despite such criticisms, the Eisteddfod raises the public profile of Guernesiais through media coverage, and allows participants to express pride in their linguistic identity, which is important for prestige- and awareness-raising. However, it does not necessarily promote use of Guernesiais (indeed, rehearsals are usually held in English): the focus is on linguistic identity as display rather than on maintaining language as a living part of everyday life. Many people who take part and win prizes do not speak it with their friends and families.

The other main focus of 'bottom-up' language support efforts is voluntary after-school lessons. Guernesiais has never been part of the school curriculum, so formal education, a domain which is usually the preserve of government, has become a focus of grass-roots language activity; this is not uncommon in minority-language support campaigns.

The current Guernesiais teaching scheme was instigated in 2004 with the support of a member of the island parliament, but it is run on an entirely voluntary basis, with no government finance and few ready-made materials. Although the lessons are unofficial, optional and extracurricular, they were seen as a potential step towards government recognition (the incorporation of Guernesiais into the mainstream curriculum is still beyond the distant horizon). Volunteers go to schools once a week to run half-hour extra-curricular sessions in lunch hours or after school. These lessons are popular and have spread from four to eight primary schools (out of 12 public and two private schools). In the early days there was considerable interest from parents, who also attended some classes, but this seems to have dwindled and teachers report that drop-out rates from the classes are high.

Voluntary and charitable work is a strong tradition in Guernsey, but it also has disadvantages: in the extra-curricular lessons there is no syllabus, no teacher training and no accountability. To date there is no evidence that any of the learners have progressed beyond beginner level. As with rehearsed performances at language festivals, many of the volunteer teachers find it easier to use Guernesiais in the relatively predictable, formal context of the classroom than in natural conversation. Another potential problem is that the lessons take up most of the available time and energy of the relatively small circle of people involved in language-related activities, which may have led to a decrease in other activities.

There are three evening and two lunchtime classes for adult learners of Guernesiais, but they currently extend no higher than elementary level. As in Jersey, there is increasing concern that there will be discontinuity of use after the disappearance of traditional native speakers, as there are not enough proficient younger adults to form a new community of speakers and take over as teachers or custodians of Guernesiais.

\section{Government Support and Policy-Making}


By 2007 it was clear that there was considerable public support for the maintenance of Guernesiais. Perhaps due to awareness- raising by language associations, opinion among the majority Anglophone community seemed to have transmuted from the traditional view of Guernesiais as a deficit variety to assigning it value, even prestige, as a marker of cultural and political distinctiveness (Sallabank, 2013; see also Johnson, 2010 regarding Jersey). This was reflected in government rhetoric. The Foreword to the first edition of the Guernsey Cultural Strategy 2010-14 stated:

Our difference from everywhere else in the world is what makes Guernsey unique and if we wish to remain unique and independent we must use every opportunity and every difference that we have from the rest of the world to make that case. Why is it important to promote and preserve our differences? I offer a simple answer, and one that has been used widely by others - extinction is forever. Our Guernsey French language is an example of what we could lose unless we take the appropriate steps to preserve it. (Culture and Leisure Department, 2010, p. 1)

As part of this new stress on language as an important aspect of island heritage, in late 2007 the Guernsey government followed the example of the Isle of Man and Jersey by approving the appointment of a Language Support Officer (LSO). However, unlike its counterparts, this post was directly funded by government rather than through a not-for-profit organization.

The establishment of a LSO acted as a catalyst for language-related activity, such as requests for lessons at all levels of education from pre-primary to sixth form, and an increase in Guernesiais in the print environment, especially signs at parish boundaries, sports facilities, and public places such as La Piaeche dla Libératiaon (Liberation Square). The growth in awareness led to unsolicited requests from private enterprises such as a coffee company, a jewellery shop, and the Guernsey Dairy for help with Guernesiais-language labelling: a case of macro language planning influencing the micro level. A 'phrase of the week' is still broadcast by the local commercial radio station ${ }^{15}$ and published in the local newspaper, with audio on its website. ${ }^{16}$

Although some prominent campaigners had called for a LSO to support their efforts and reduce the risk of 'burnout', for some volunteers government intervention raised fears of interference and of devaluation of voluntary efforts. As discussed in Marquis and Sallabank (2013), from the beginning there were disagreements over the definition of 'support' in the job title and about the direction and control of language policy. As a result of these divisions, the first and only LSO, Yan Marquis, resigned in July 2011 and has not been replaced.

After Marquis' resignation government language policy-making in Guernsey remained fairly dormant until after the 2012 elections. In February 2013 one of the new Deputies, Darren Duquemin, announced the formation of a 'Language Commission' to coordinate language support and revitalization efforts. 
In an attempt to circumvent intra-communal and ideological disagreements such as those which thwarted the previous government policy, the Language Commission is composed of people who have little previous involvement in language-related activities and are not associated with any factions, but who have expertise in fundraising, marketing and public relations. The main drawback to this approach is that the members of the Commission know very little about the language itself or about language policy and planning. The Commission has only a small government budget but aims to raise money for specific projects; it is unclear to what extent it will exercise a strategic overview. The Commission does not seek to supplant grass-roots efforts but to support and supplement them: effectively macro-level planning in support of microplanning, although the government's motivation is still arguably to promote island distinctiveness. The Commission's 'mission statement' is:

Whether we are fluent or just use a few phrases, islanders of all ages are proud of Guernsey's language.

At the time of writing, the Commission is still at an early stage. It has started a website and Facebook page ${ }^{17}$ to act as a central source of information for those interested in the language,$^{18}$ and funded the former Language Officer, Yan Marquis, to record remaining traditional speakers of Guernesiais. It has also subsidised additional adult classes, and in January 2014 launched a Guernsey Song Project which encourages songwriters to write songs (or refrains) in Guernesiais, and pairs them with more fluent speakers to provide language input. ${ }^{19}$

\section{Future Opportunities and Challenges}

Language documentation is seen as a priority given that despite more positive attitudes, revitalization efforts to date have not yet increased the number of fluent speakers. In such circumstances, reliable records of how Guernesiais is used and pronounced will play an essential role for future reference.

The focus of language policy is gradually shifting to developing new adult speakers, who are seen as an essential link in language transmission. The Guernsey Song Project is also bringing together some members of the traditional and 'new speaker' language communities. It is hoped that this will both help to heal rifts, and motivate more sustained language learning and use.

\section{Comparing Language Revitalization in Jersey, Guernsey and the Isle of Man}

In all three islands in this comparative study, awareness-raising by voluntary groups has contributed to a general climate of support for local languages. Much of this has involved what might be called prestige and image planning (Haarmann, 1990; Ager, 2005), either overtly or 
implicitly (most grassroots campaigners are not aware of the concepts). Awareness-raising is an important step in campaigning for an endangered language, especially if the support of government agencies is sought. It can also be argued that it is a pre-requisite for the acceptance and success of other measures, as any publicly funded measures would require the support of the Anglophone majority. However, prestige and image planning do not necessarily alter language practices; as a result, measures risk remaining at the symbolic level. Guernesiais and Jèrriais remain highly endangered, with no intergenerational transmission and few successful second language learners. By comparison, there is some optimism that Manx will grow in the wake of successful education planning programs. But the prognosis for this language, like Guernesiais and Jèrriais, is still extremely critical. In all three cases, most language-related activities are undertaken by a relatively small number of people, many of whom are volunteers with other commitments.

These cases offer a number of intriguing insights on the process of language revitalization and, in particular, the (inter)relationship between grassroots activism and government involvement. Aside from the general political, economic and demographic similarities between each island and the obvious precariousness of their indigenous languages, they reveal a fairly recent upsurge in language activism, coupled with varying levels of government support aimed primarily at educational and cultural activities. That being said, it also appears that government involvement is also predicated on the notion that language and culture can help to distinguish these places in an increasingly competitive, global economy. This could prove to be very important in terms of government support for the language in the future, as these islands face considerable pressure from external economic and political forces. The political and economic autonomy that each of these islands holds has been an important factor in the revitalization process.

Similarities aside, a closer examination of these three cases reveals a number of important differences in terms of the structure, cohesion and scope of the language revitalization process. Despite the fact that Manx is considered the most endangered of all three languages, because it no longer has native speakers, the institutional organization of the grassroots community on the Isle of Man is more robust and embedded. For example, the position of the Manx Language Officer (MLO) has been in place for much longer than the corresponding offices in Jersey and Guernsey. Its work is complemented by other bodies and organisations and it is based in a notfor-profit organization, rather than a department of government. While the MHF receives some funding from the government, it has considerable autonomy to pursue its own goals and objectives. This arrangement creates space between the government and the language community, so that the government can play a supportive, but not a controlling role in the language revitalization process. In the case of Guernsey, the Language Support Officer (LSO) was based directly in a Government Ministry and this contributed to the tension and interference that ultimately led to the resignation of the LSO in 2011. Like the Isle of Man, L'Office du Jèrriais in Jersey has a language officer and receives some government funding but operates at arm's length from the States of Jersey. 
One feature that differentiates the language communities in these small island jurisdictions is the presence of native language speakers. Whereas native speakers are still prominent in parts of the speech community in Jersey and Guernsey, this is not the case in the Isle of Man. ${ }^{20}$ In some respects, the absence of native speakers places Manx in a much more precarious position compared to Guernesiais and Jèrriais. In other cases, the death of the last native speaker has resulted in the extinction of a language. While this has not happened in the case of Manx, it may also be true that the absence of older native speakers has focused language revitalization efforts by mitigating divisions between traditionalists and new speakers of the language, in corpus planning and efforts towards standardization. Such divisions are evident in Guernsey and have clearly affected the cohesion and common purpose of language support efforts.

Over the past few decades, language revitalization efforts in the Isle of Man, Jersey and Guernsey have moved beyond the narrow confines of festivals and other cultural events, and back into mainstream, everyday activities such as the education system. There are, however, important differences in the scope and focus of language planning. This is a positive development because promoting language as an identity marker, in events such as language festivals, does not necessarily increase its vitality or use (although education is not guaranteed to either). As Sallabank (2011, p. 34) points out: "There is also a risk that such activities become an end in themselves rather than elements of a wider language strategy. They may even take the place of day-to-day use, as it is easier for learners and semi-speakers to cope with controlled, predictable language."

An important component of language revitalization in all three jurisdictions has been the development of programs whose objective is to encourage younger generations to learn the language. The hope is that a younger generation of speakers and learners will become the activists of tomorrow, carrying on the important work that has been accomplished by the current generation of activists. In the Isle of Man, the scope of education programming is very broad (but not compulsory), encompassing pre-school, primary, secondary and adult education. The centrepiece of this programming is the Manx immersion program offered at the primary level through the Bunscoill Ghaelgagh, which has 69 children at the time of writing. The Government plays a supportive but generally non-intrusive role, leaving much of the planning to educators within the school system, the MLO, the Manx Language Unit, and not-for-profit organizations like the Mooinjer Veggey program and the Manx Heritage Foundation.

In Guernsey and Jersey, the indigenous languages are less prominent within the education system; they do not form part of the compulsory curriculum and are taught outside school hours.A constraint on the effectiveness of the voluntary lessons is the limited 'time on task' for language learning. Not only are the lessons themselves short (in many cases only 30 minutes per week in term time, i.e. only 20 hours per year), the amount of quality language input that the children receive within those lessons is even less. For adult learners too, lessons alone cannot provide the amount of practice needed to develop fluency. 
In all three islands, the education system struggles to find qualified teachers who are also fluent speakers. Efforts, therefore, need to focus on making adult learning effective, because without proficient adults there will be no younger learners. Adrian Cain, the Manx Language Development Officer, has pointed out that even at the lowest ebb of support for Manx, there was a core of adult second-language speakers who kept it alive as a language of communication (personal communication, July 2013). Developing such a core of committed learners, together with effective teacher training, would therefore seem to be an essential part of a language strategy for Jèrriais and Guernesiais 'going forward'. In order to be sustainable, a 'new speaker' community has to extend beyond formal lessons, in order to provide a social network for latent or lapsed speakers as well as those learning from scratch. To this end the MLO is encouraging social interaction in Manx, in public places such as cafés and pubs; in Guernsey too, 'Guernesiais in the pub' sessions have been started.

In all three islands, grassroots activists have been at the heart of the revitalization struggle. As Tadhg Ó hlfearnáin comments in the case of the Isle of Man:

the revitalization of Manx has always depended most on the dedication of individuals and small groups of enthusiasts, who have worked hard not simply to preserve Manx, but to cultivate the language, especially during times when there was often little support in the wider community (Pobble, 2013)

Grass-roots activism may be 'necessary but not sufficient' for language revitalization, in that government support can provide more resources and direction than small groups of volunteers. Although public support for language revitalization has grown, a process that, in turn, strengthens government interest and involvement, such support is often passive and does not necessarily translate into grassroots activism. In addition, government support in these three jurisdictions tends to promote the symbolic use of language for political distinctiveness, which does not necessarily require fluent use of Manx, Jèrriais or Guernesiais as living languages. As such, there is a pressing need to continue to cultivate and grow the community of grassroots activists and develop new speaker communities. In all three cases, it appears that a small cohort of dedicated activists performs much of the 'heavy lifting' associated with language revitalization. This may encourage cohesion and efficiency, but it can also lead to burnout and frustration. The key to future success, therefore, will be to spread the work out among a larger cohort of active and dedicated activists, and preferably amongst a new and younger community of fluent speakers.

\section{Works Cited}

Ager, Dennis E. (2005). Prestige and image planning. Current Issues in Language Planning 6, 143. 
Badlabecques. (2012). Héque Badlabecques! Jersey: Music Core.

Baldauf, R. B., Jr. (1994). "Unplanned" Language Policy and Planning. Annual Review of Applied Linguistics, 14, 82-89.

Britain, David. (Ed.). (2007). Language in the British Isles. Cambridge: Cambridge University Press.

British-Irish Council. (2012). About. http://www.britishirishcouncil.org/about (Date accessed: May 15, 2012).

Clague, Marie. (2009). "Manx Language Revitalization and Immersion Education." e-Keltoi: Journal of Interdisciplinary Celtic Studies, 2, 165-198.

Council of Europe. (2010). European Charter for regional or minority languages; Application of the Charter in the United Kingdom: $3^{\text {rd }}$ Monitoring Cycle. Strasbourg: Council of Europe.

Crossan, Rose-Marie. (2005). The retreat of French from Guernsey's public primary schools, 1800-1939. Transactions of La Société Guernesiaise XXV, 851-888.

Culture and Leisure Department. (2010). Our Way of Life: A Cultural Strategy for Guernsey 2010-14. Guernsey: States of Guernsey.

Fennell, Desmond. (1981). "Can a shrinking minority be saved? Lessons from the Irish experience.” In Einar Haugen, J. Derrick McClure and Derick Thompson (Eds). Minority Languages Today: A Selection from the Papers Read at the First Conference on Minority Languages at Glasgow University 8-3 September 1980. (pp. 32-39). Edinburgh: Edinburgh University Press.

Fleury, Christian and Johnson, Henry. (2013). "Le phénomène de revitalisation culturelle à Jersey: Un exemple d'accompagnement symbolique à la mondialisation." Annales de Géographie 690, 200-219.

Gawne, Philip. (2002). "Securing the Future for Manx Gaelic.” In Peter Davey, David Finlayson and Philippa Tomlinson (eds). Mannin Revisited: Twelve Essays on Manx Culture and Environment (pp. 173-183). Edinburgh: Scottish Society for Northern Studies).

Grenoble, Lenore A. and Whaley, Lindsay J. (2006). Saving Languages: An Introduction to Language Revitalization. Cambridge: Cambridge University Press. 
Haarmann, Harald. (1990). Language planning in the light of a general theory of language: a methodological framework. International Journal of the Sociology of Language 86,103-26.

Hobsbawm, Eric J. and Ranger, Terence O. (Eds.). (1983). The Invention of Tradition: Cambridge: Cambridge University Press.

Isle of Man Government. (2013). Island Facts. Retrieved from http://www.gov.im/categories/business-and-industries/iom-key-facts-guide/island-facts/

Johnson, Henry. (2008). "Localising Jersey through song: Jèrriais, heritage and island identity in a festival context." Shima: The International Journal of Research into Islands Cultures, 2 (1), 73-98.

. (2010). "Branding Jèrri: art, image, and identity in contexts that celebrate Jersey's Norman heritage.” Refereed papers from the Sixth International Small Island Cultures Conference, Guernsey, June 23-25 2010.Retrieved from http://sicrinetwork.org/ISIC6/e.\%20ISIC6P\%20Johnson.pdf.

Jones, Mari C. (2000). "Swimming against the tide: Language planning on Jersey." Language Problems \& Language Planning, 24 (2), 167-96.

. (2001). Jersey Norman French: A linguistic study of an obsolescent dialect. Blackwell: Oxford. . (2007). "Channel Islands French" In David Britain (ed). Language in the British Isles (pp. 358-367). Cambridge: Cambridge University Press.

Jones, Mari C. and Ishtla Singh. (2005). Exploring language change. New York: Routledge.

Kaplan, Robert B., and Richard B. Baldauf. (1997). Language Planning: From Practice to Theory. Clevedon: Multilingual Matters.

Kermode, David G. (2001). Offshore Island Politics. The Constitutional and Political Development of the Isle of Man in the Twentieth Century. Liverpool: Liverpool University Press

Le Rendu, Luke. (2004). Jersey: Independent dependency? The survival strategies of a microstate. Bradford on Avon: ELSP.

L'Office du Jèrriais. (2012). Jèrri chîn' et là. St Saviour: The States of Jersey.

Manx Heritage Foundation. (2013). Retrieved from http://www.manxheritage.org/ 
Marquis, Yan, and Sallabank, Julia. 2013. "Speakers and language revitalisation: a case study of Guernesiais (Guernsey).” In Mari C. Jones and Sarah Ogilvie (eds). Language Endangerment: Documentation, Pedagogy, and Revitalization. Cambridge: Cambridge University Press.

Mooinjer Veggey. (2013). Retrieved from http://www.mooinjerveggey.org.im/

Pobble: Supporting Manx Gaelic as a Community Asset. (2013). Retrieved from http://www.learnmanx.com/cms/media//News/Pobble\%20prospectus\%20(proof).pdf

Qualtrough, James. (2012). "Facebook Now in Manx Gaelic.” isle of man.com. Retrieved from http://isleofman.isle-news.com/archives/facebook-now-in-manx-gaelic/15232/.

Riddell, A. (2007). "Jersey: The development of an island cultural strategy." Shima: The International Journal of Research into Island Cultures 1, 72-87.

Sallabank, Julia. (2005). "Prestige From the Bottom Up: A Review of Language Planning in Guernsey." Current Issues in Language Planning, 6, 44-63.

. (2006). "Guernsey French, identity and language endangerment." In Tope Omoniyi and Goodith White (Eds.). The Sociolinguistics of Identity (pp. 131-156). London: Continuum. . (2011). "Norman languages of the Channel Islands: Current situation, language maintenance and revitalisation." Shima: The International Journal of Research into Island Cultures.5, 16-41.

. (2013). "Can majority support save an endangered language? A case study of language attitudes in Guernsey." Journal of Multilingual and Multicultural Development. Special Issue on Attitudes towards Endangered Languages, 34, 332-347.

States of Jersey. (2006a). Official Report. 22 June 2006a. St Helier: States of Jersey. . (2006b). Strategic Plan 2006-2011. St Helier: States of Jersey. . (2009). Strategic Plan 2009-2014. St Helier: States of Jersey. . (2010). Education and Home Affairs Panel Hearing: Cultural Strategy Review, 5 October. Retrieved from www.statesassembly.gov.je. 
States of Jersey, Education, Sport and Culture Committee. (2005a). Development of a Cultural Strategy for the Island. Lodged on 19 July 2005 by the Education, Sport and Culture Committee. St Helier: States Greffe. Retrieved from www.statesassembly.gov.je.

. (2005b). Jerriais: Provision in Jersey Schools. Written report presented to the States on 9 August 2005 by the Education, Sport and Culture Committee. St Helier: States Greffe. Retrieved from www.statesassembly.gov.je.

States of Jersey Statistics Unit. (2012a). Jersey in Figures, 2012. St Helier: States of Jersey Statistics Unit.

. (2012b). Jersey's Resident Population 2012. St Helier: States of Jersey Statistics Unit.

Trudgill, Peter. (Ed.). (1984). Language in the British Isles. Cambridge: Cambridge University Press.

Wilkins, David P. (2000). "Even with the best of intentions ...' : Some Pitfalls in the Fight for Linguistic and Cultural Survival (One view of the Australian Experience).” In Francisco Queixalos and O. Renault-Lescure (Eds.). As linguas amazônicas hoje / Les langues d'Amazonie aujourd'hui. Belem: Museu Goeldi/IRD/ISA/MPEG.

Wilson, Gary N. (2008). "The Revitalization of the Manx Language and Culture in an Era of Global Change." Refereed papers from the $3^{\text {rd }}$ international Small Island Cultures Conference (74-81). Charlottetown: Institute of Island Studies, University of Prince Edward Island, June 29July 2, 2007.

. (2009). "But the Language Has Got Children Now: Language Revitalisation and Education Planning in the Isle of Man." Shima: The International Journal of Research into Island Cultures, 3/2, 15-31.

. (2010). "Social Change and Language Revitalization in the Isle of Man: A PostMaterialist Perspective." In Julia Sallabank (ed). Language Documentation and Description. Vol. 9 (58-74) London: School of Oriental and African Studies.

Ynsee Gaelg. (2013). Retrieved from http://www.learnmanx.com/

\footnotetext{
${ }^{1}$ The term "island jurisdiction" is used purposefully to refer to territories that are not formally recognized as nation states (i.e. countries), but that are also not parts of other states (i.e. provinces or regions)
} 
${ }^{2}$ The authors recognize that the term "British Isles" is controversial and is not universally accepted by all of the countries and regions in this geographical area. It is, however, a term that is accepted and used in the three cases under examination in this article.

${ }^{3}$ The UK government is responsible, following consultation, for international relations and defense. Each island has a special relationship with the EU as a result of the UK's accession to the European Economic Community (later European Union) in 1972. ${ }^{4}$ There are two Manx Language Officers. Adrian Cain works for the Manx Heritage Foundation, and Rob Teare, the Head of the Manx Language Unit (Yn Unnid Gaelgagh) works for the Department of Education.

${ }^{5}$ The rest of the MHF's funding comes from a lottery grant and other miscellaneous income and revenue.

${ }^{6}$ In Manx: People, Community, Folk

${ }^{7}$ Jersey Language Office

${ }^{8}$ The Assembly of Jersey People

${ }^{9}$ See www.jerriais.org.je.

${ }^{10}$ See reports at www.statesassembly.gov.je.

${ }^{11}$ The Fête is held annually and rotated each year amongst the three main Norman centers: Jersey, Guernsey and mainland Normandy.

${ }^{12}$ The Guernsey variety of Norman does not have an official name, which reflects its low status. In Julia Sallabank's research 'Guernesiais' was the name preferred by speakers. It is also commonly known as 'Guernsey French' or 'the patois'; the 2001 Census used the term 'Guernsey Norman-French' to avoid ambiguity.

${ }^{13}$ There are no current official figures: the 2006 census was cancelled for financial reasons and from 2010 censuses were replaced by annual population bulletins which do not include language information.

${ }^{14}$ Both the Jersey and Guernsey Eisteddfod cultural festivals were inspired by the Welsh Eisteddfodau.

${ }^{15} \mathrm{http}: / /$ www.islandfm.com/local/info.php?refnum=3087, accessed 27 January 2014

16 http://guernseypress.com/community/history-heritage/donkey-dialogue/donkey-dialogue-2/, accessed 27 January 2014.

${ }^{17} \mathrm{https} / / / w w w . f a c e b o o k . c o m / G u e r n e s i a i s$, accessed 27 January 2014.

${ }^{18}$ www.language.gg, accessed 26 January 2014.

${ }^{19} \mathrm{http} / / / \mathrm{www}$.guernseysongproject.org.gg/, accessed 27 January 2014.

${ }^{20}$ Some would claim there are some child 'neo-native' speakers in the Isle of Man (children that have grown up speaking Manx as a first language). The authors recognize that terms such as 'native speaker' are contested. 